\title{
Effects of Two Heights and Three Intervals of Grazing on the Productivity of a Heavily Fertilized Pangola Grass Pasture, ${ }^{1,2}$
}

\author{
José Vicente-Chandler, Servando Silva, \\ José Rodriguez, and Fernando Abruña ${ }^{3}$
}

\section{INTRODUCTION}

Pangola grass (Digitaria decumbens) is the most widely used pasture grass in the humid region of Puerto Rico. Caro, Vicente-Chandler and Abruña (2) found that Pangola grass pastures responded in terms of beef production and carrying capacity to applications of up to 2,400 pounds of 14-4-10 fertilizer per acre yearly. Caro, Vicente-Chandler, and Figarella (3) found that Pangola, Napier and Guinea grass pastures receiving 2,000 pounds of 14-4-10 fertilizer per acre yearly produced similar yields, averaging 1,065 pounds of gain in weight per acre yearly.

Vicente-Chandler, Figarella and Silva (4) found that yields of Pangola grass harvested by cutting close to the ground increased with length of harvest interval up to 60 days. Caro and Vicente-Chandler (1) found that higher yields were obtained when heavily fertilized Pangola grass cut every 60 days was harvested by cutting to a height of 0 to 3 inches above the the ground than when it was cut to a height of 7 to 10 inches. Little research, however, has been conducted on the effects of grazing intervals and grazing heights on the productivity of Pangola grass pastures.

The present study was conducted for the purpose of determining the effect of two heights of grazing and three grazing intervals, and their interactions, on yields of Pangola grass actually consumed by cattle grazing relatively small fenced plots.

\section{MATERIALS AND METHODS}

The experiment was carried out over a 1-year period under conditions typical of the humid mountain region of Puerto Rico, at the Corozal Sub-

1 Manuscript submitted to Editorial Board August 23, 1971.

2 This report covers work conducted cooperatively by the Soil and Water Conservation Research Division, Agricultural Research Service, USDA, and the Agricultural Experiment Station, Mayaguez Campus, University of Puerto Rico, Río Piedras, P.R.

3 Project Leader-Soil Scientist and Agricultural Technician, Soil and Water Conservation Research Division, ARS, USDA, Río Piedras, P.R., Research Assistant, Agricultural Experiment Station, Mayaguez Campus, University of Puerto Rico, Corozal, P.R., and Soil Scientist, Soil and Water Conservation Research Division, ARS, USDA, Río Piedras, P.R., respectively. 
station of the Agricultural Experiment Station, Mayaguez Campus, University of Puerto Rico. Annual rainfall was about 75 inches, well distributed throughout the year except for a dry period from January through March. The soil is a deep, red, Corozal clay (Ultisol).

The following treatments were tested using a split plot design with five replications:

Grazing height (main plots)-A (low): Forage grazed to a height of about 2 inches from the ground; $B$ (high): forage grazed to height of about 6 inches from the ground.

Grazing frequency (sub-plots)-1, Grazed every 14 days; 2 , grazed every 21 days; 3 , grazed every 28 days.

Plots were 30 feet X 30 feet each surrounded by a barbed and chicken wire fence to prevent cattle from grazing adjacent plots.

A pure stand of Pangola grass was established in all plots. The soil was limed to about $\mathrm{pH} 5.5$ and 2,000 pounds of 14-4-10 fertilizer were applied per acre yearly to all plots in four equal applications.

At the specified intervals two young Holstein heifers were allowed to graze the grass in each plot down to the required height, which they accomplished in 1 to 2 days. Yield of forage consumed by the cattle in each plot was determined at each grazing by the following method. Before each grazing, the forage in five randomly selected 1-square-foot areas in each plot was cut close to the ground, dried and weighed. After the cattle were removed, the forage remaining in five other 1-square-foot areas was determined in a like manner. From these data the forage actually consumed by the grazing cattle was calculated by subtracting the quantity of forage remaining in the plots after grazing from that available before grazing.

\section{RESULTS AND DISCUSSION}

Table 1 shows that higher yields of forage were obtained when the grass was grazed to about 6 inches than when it was grazed to about 2 inches from the ground irrespective of grazing frequency. An average of 13,096 pounds of dry forage were consumed per acre yearly by cattle grazing the pastures to a height of 6 inches compared to only 9,677 pounds with closer grazing.

The table also shows that yields of forage decreased with increasing length of grazing interval irrespective of grazing heights. An average of $12,640,11,568$ and 9,951 pounds of dry forage per acre yearly were consumed by grazing cattle at grazing intervals of 14,21 and 28 days, respectively.

There was no significant interaction between grazing height and frequency of grazing.

The yields obtained in this experiment are similar to those obtained by Caro, Vicente-Chandler and Figarella (3) in a large-scale grazing experiment 
under similar climatic and management conditions. Forage consumed by the eattle in this experiment, as determined by a "difference" method similar to that employed in the present study, averaged 11,950 pounds of dry forage per acre yearly.

The lower yields obtained with the longer grazing intervals can be explained by greater trampling losses resulting from lodging of this weakstemmed grass when it is allowed to grow tall before grazing. With cutting management, all forage produced by this grass can be harvested, and yields increase with length of harvest interval as shown by Vicente-Chandler, Figarella and Silva (4).

The higher yields obtained with high grazing can be attributed to the

TABLE 1.-Effect of two grazing heights and three grazing intervals on productivily of

a Pangola grass pasture in the humid mounlain region of Puerto Rico over a 1-year period

\begin{tabular}{cccc}
\hline \multicolumn{4}{c}{ Yields of dry forage consumed by grazing cattle } \\
\hline $\begin{array}{c}\text { Grazing frequency } \\
\text { (days) }\end{array}$ & High grazing $^{1}$ & Low grazing $^{2}$ & Average \\
\cline { 2 - 4 } & & (Pounds per acre yearly) \\
\hline 14 & 14,271 & 11,009 & 12,640 \\
21 & 13,152 & 9,984 & 11,568 \\
28 & 11,866 & 8,037 & 9,951 \\
\hline Average & 13,096 & 9,677 & \\
\hline
\end{tabular}

L.S.D. ${ }^{05}$ for grazing frequency $=2,656$

L.S.D. ${ }^{05}$ for grazing height $=2,142$

1 Forage grazed to a height of about 6 inches from the ground.

2 Forage grazed to a height of about 2 inches from the ground.

greater photosynthetic area remaining after grazing, enabling the grass to recover more rapidly. Grass closely grazed must draw on its root reserves to resume growth after each grazing. With the much longer harvest interval (60 days) used by Caro and Vicente-Chandler (1) this factor is relatively unimportant and higher yields of Pangola grass are obtained by cutting close to the ground.

The use of longer grazing intervals would be expected to ameliorate the depressing effect of close grazing on yield. This effect was apparently offset, however, by increased trampling losses with the longer grazing intervals as discussed above.

It probably is best to graze heavily fertilized Pangola grass pastures to a height of about 6 inches from the ground about every 14 days during seasons of fast growth and every 21 days during seasons of slow growth. 
The technique used in this experiment offers possibilities, despite its limitations, for determining the productivity of different grasses and the effect of varying management systems under actual grazing conditions at much lower costs than are incurred in large scale grazing experiments.

\section{SUMMARY}

The effects of two grazing heights and three different grazing intervals on yields of Pangola grass were determined under actual grazing management over a 1-year period. Yields of forage actually consumed by the grazing cattle were determined by sampling small fenced plots before and after each grazing round and determining by difference the forage consumed.

Higher yields of forage were obtained when the grass was grazed to within about 6 inches of the ground than with close grazing (an average of 13,096 vs 9,677 pounds of dry forage per acre yearly). Yields of forage decreased with increasing length of grazing interval averaging 12,640,11,568 and 9,951 pounds of dry forage per acre yearly, with grazing intervals of 14,21 and 28 days, respectively. There was no significant interaction between grazing height and frequency of grazing. It appears best to graze heavily fertilized Pangola grass pastures to about 6 inches from the ground about every 2 weeks during seasons of fast growth and every 3 weeks during seasons of slow growth.

\section{RESUMEN}

Se determinó el efecto de dos alturas y tres diversos intervalos de pastoreo en la producción de pastos de yerba Pangola durante un año. Se determinó el forraje ingerido por el ganado que pastaba en pequeñas parcelas mediante un sistema de muestreo que permitió estimar el forraje existente en las parcelas antes y después de cada pastoreo. De estos datos se determinó por diferencia el forraje ingerido por el ganado.

La cantidad de forraje ingerido por el ganado fue mayor cuando la yerba Pangola se pastoré hasta una altura de unas 6 pulgadas que cuando se pastoré hasta unas 2 pulgadas de la tierra (13,096 vs 9,677 libras de forraje seco por acre al año). La producción de forraje se redujo según aumentó el intervalo del pastoreo. El ganado ingirió un promedio de $12,640,11,568$ y 9,951 libras de forraje seco por acre al affo cuando se pastorearon las parcelas cada 14, 21 y 28 días, respectivamente. No hubo interacción significativa entre la altura del pasto y el intervalo del pastoreo. Parece aconsejable pastar la yerba Pangola bien abonada hasta una altura de unas 6 pulgadas cada 2 semanas durante épocas de crecimiento rápido y cada 3 semanas durante épocas de poco crecimiento.

\section{LITERATURE CITED}

1. Caro-Costas, R., and Vicente-Chandler, J., Effect of two cutting heights on yields of five tropical grasses, J. Agr. Univ. P.R. 45 (1): 46-9, 1961.

2. Caro-Costas, R., Vicente-Chandler, J., and Abruña, F., The effect of four levels of fertilization on beef production and carrying capacity of Pangola grass pastures in the humid mountain region of Puerto Rico. (In press.) 
114 JOURNAL OF AGRICULTURE OF UNIVERSTTY OF PUERTO RICO

3. Caro-Costas, R., Vicente-Chandler, J., and Figarella, J., Productivity of intensively managed pastures of five grasses on steep slopes in the humid mountain region of Puerto Rico, J. Agr. Univ. P.R. 49 (1): 79-111, 1963.

4. Vicente-Chandler, J., Figarella, J., and Silva, S., Effect of nitrogen fertilization and frequency of cutting on the yield and composition of Pangola grass, J. Agr. Univ. P.R. 45 (1): 37-45, 1961. 